\title{
Издания геологического факультета Пермского государственного университета (2015)
}

\section{И.К. Трубина}

Пермский государственный национальный исследовательский университет, 614990, Пермь, ул. Букирева, 15. E-mail: mineral@psu.ru

Приведены библиография и краткие аннотации монографий, учебных пособий и тематических сборников статей сотрудников геологического факультета Пермского госуниверситета за 2015 г.

Ключевые слова: геология, библиография, Пермский госуниверситет.

DOI: $10.17072 /$ psu.geol.32.75

\section{Монографии}

Баяндина Э.О. Нерастворимый остаток солей Верхнекамского месторождения / Э.О. Баяндина, А.И. Кудряшов. Пермь: ООО «Типограф», 2015. 102 с.

В книге даны краткое описание геологического строения Верхнекамского месторождения солей (общие сведения, стратиграфия, литология, тектоника) и характеристика нерастворимого в воде остатка его солей - формы нахождения, гранулометрический и минеральный состав, генезис, а также описание влияния этого компонента на процессы освоения месторождения. Приведены сведения о методике опробования солей, первичной обработке проб, методике и погрешности определения содержания нерастворимого остатка.

Бычков С.Г. Вычисление аномалий силы тяжести при высокоточных гравиметрических съемках / С.Г. Бычков, А.С. Долгаль, А.А. Симанов; УрО РАН. Пермь, 2015. $142 \mathrm{c}$.

В работе выполнен критический анализ существующих стандартов редуцирования полевых гравиметрических данных.
Показано, что повышение точности современных гравиметрических съемок требует пересмотра стандартных процедур редуцирования наблюденных значений силы тяжести. Предложены новые формулы для вычисления нормального гравитационного поля и его вертикального градиента, которые базируются на современных данных о фигуре Земли. Показаны ошибки, обусловленные заменой реального сферического промежуточного слоя плоскопараллельным. Обосновано использование эллипсоидальных высот при обработке гравиметрических данных. Для определения поправок за влияние рельефа местности разработана технология, базирующаяся на прогрессивных методах подготовки первичной картографической информации и на современном математическом аппарате, которая позволяет получить результат с априорно заданной точностью.

Золото-алмазная колыбель России: монография / И.С. Копылов, В.А. Наумов, О.Б. Наумова, Т.В. Харитонов; под общ. ред. В.А. Наумова; Перм. гос. нац. исслед. ун-т. Пермь, 2015. 132 с. 
Монография включает три раздела. В первом разделе «Краткий геологический очерк территории» представлены геологическое описание Пермского края, Свердловский области, их тектоническое районирование, дается характеристика вещественно-тектонических комплексов. Во втором («Исторический очерк поисков золота и алмазов на Среднем Урале») рассмотрены исторические аспекты и сделан анализ работ по поискам золота и алмазов в Уральском регионе от первых открытий до современного состояния геологической отрасли. В третьем разделе приводится краткое описание геологических объектов и памятников природы по маршруту геологической экскурсии трассы ПермьЕкатеринбург.

Караваева Т.И. Природно-техногенные системы: экологические перспективы использования: монография / Т.И. Караваева, В.П. Тихонов. Пермь, 2015.150 с.

На основе обобщения многолетнего опыта работ по экологическому сопровождению разработки россыпных месторождений полезных ископаемых в монографии рассматриваются методические основы и практические способы решения экологических проблем недропользования по очистке поверхностных вод от взвешенных веществ. Анализ новых свойств аллювиально-техногенных отложений позволил разработать систему очистки воды, основанную на регулируемой фильтрации и равномерном заполнении порового пространства частицами глинистой размерности. Система очистки показала высокую эффективность на различных полигонах работ. Разработана теоретическая основа создания искусственных фильтрационно-сорбционных систем для чистки воды практически в любых природных условиях разработки месторождения.

Коссовая О.Л. Middle Urals. Carboniferous and Permian marine and continental successions / О.Л. Коссовая, И.С. Хопта, Г.Ю. Пономарева. Пермь: Астер, 2015. $224 \mathrm{c}$.
В книге даны описание и биостратиграфический анализ важных типов и опорных разрезов фамена, карбона и нижней перми. Фораминиферы, конодонты, кораллы ругоза проиллюстрированы.

Минерально-сырьевая база Пермского края для производства базальтового волокна: справочник / С.М. Блинов и др.; под ред. Р.Г. Ибламинова; Перм. гос. нац. исслед. ун-т. Пермь, 2015. 269 с.

Для территории западного склона Северного Урала приведена характеристика комплексов и отдельных тел магматических горных пород с оценкой пригодности в производстве базальтового волокна. Рассмотрены минерагенические закономерности размещения пород, их описание, приведены результаты минералогических, геохимических, термовесовых исследований. Описание сопровождается многочисленными фотографиями и обобщениями материалов прецизионных методов исследования.

Монография написана в результате выполнения проекта «Оценка минерально-сырьевой базы Пермского края для обеспечения производства высокотехнологичного базальтового волокна» в рамках приоритетного направления развития науки, технологий и техники в Российской Федерации «Рациональное природопользование и экологическая безопасность», а также «Материалы и производственные технологии нового поколения».

Применение гравиметрии и магнитометрии при изучении глубоких и близкоповерхностных неоднородностей земной коры / М.С. Чадаев, В.И. Костицын, Р.Г. Ибламинов, В.А. Гершанок, Г.В. Пролупов, М.В. Тарантин, Л.А. Гершанок, А.В. Коноплев; под общ. ред. М.С. Чадаева и Р.Г. Ибламинова. Пермь, 2015. 110 с.

В монографии последовательно рассмотрены свойства потенциала притяжения и получаемых на его основе производных, особенности применяемых систем обработки данных ВЕКТОР и ПОЛЮС. Обсуждаются вопросы корреляционной зависимости скоростных и плотностных параметров глубинных слоев 
земной коры. Приведены отдельные результаты изучения земной коры на территории Пермского края, Республики Коми, Архангельской области и акватории Баренцева и Карского морей.

Сейсмичность и сейсмическое районирование слабоактивных территорий / Р.А. Дягилев и др. Пермь, 2015. 178 с.

В монографии рассмотрена методика сейсмического районирования для слабоактивных территорий, разработанная на примере Западно-Уральского региона. Она позволяет прогнозировать геодинамически неустойчивые зоны с использованием геолого-геофизических данных и определять сейсмический потенциал регионов.

Шерстнев В.А. Библия и наука в круге едином? / В.А. Шерстнев. Пермь, 2015. $184 \mathrm{c}$.

Картина мироздания, происхождение человека и Всемирный потоп являются предметом многовековых научных споров. Валерий Шерстнев рассматривает эти события в той последовательности, в какой они изложены в Библии.

Многие ученые отдают дань уважения Библии как самой читаемой книге в мире, как источнику культуры и вероучений, при этом отказывая ей в научности. В. А. Шерстнев, не опровергая эту позицию, в своем издании приводит факты, сопоставляет их, задается вопросами. А выводы предоставляет делать читателю.

Шумилов А.В. Геология и технология освоения месторождений углеводородов в акваториях морей и океанов: монография / А. В. Шумилов, В. А. Шумилов; Перм. гос. нац. исслед. ун-т, Пермь, 2015. $263 \mathrm{c}$.

В монографии рассматриваются научные и практические аспекты геологических и технологических условий освоения морского рельефа в различных регионах мира. Описание и анализ геологического строения и перспектив нефтегазоносности в приграничных и окраинных морях России особенно важны в современных политических и экономических реалиях.
Монография знакомит также с типами добывающих морских платформ и буровых установок. Сопоставляются различные варианты конструкций для транспортирования сырья к потребителям. Затрагиваются вопросы экологии при разработке шельфовых месторождений нефти и газа.

Шумилов В.А Геофизические исследования скважин при разведке и добыче метана угольных пластов: монография / В.А. Шумилов, С.М. Аксельрод, А.В. Шумилов; Перм. гос. нац. исслед. ун-т. 2-е изд., доп. Пермь, 2015. 136 с.

Монография знакомит с практикой исследования, проектирования, разведки, сбора, транспортирования и утилизации метана угольных пластов в ряде стран и регионов мира.

Дается описание свойств углей как коллекторов газа и видов геофизических исследований скважин на этапах разведки и эксплуатации. Сопоставляются различные варианты конструкции скважин и технологии их бурения, обсуждаются технологические особенности добычи газа. Затрагиваются экологические аспекты разработки месторождений угольного газа.

Шумилов А.В. Проблемы организации и оснащения системы геофизического мониторинга режимов эксплуатации нефтегазовых скважин на месторождениях севера Пермского Прикамья: монография / А.В. Шумилов, И.А. Черных, Ю.А. Гуторов. Пермь, 2015. 156 с.

Дается краткий анализ причин фактической утраты нефтедобывающими предприятиями контроля над процессом разработки нефтяных месторождений, что является одним из основных факторов снижения коэффициента извлечения нефти и роста доли трудноизвлекаемых запасов.

Предлагается оснастить эксплуатационные скважины сложнопостроенных нефтяных месторождений Пермского Прикамья стационарными геофизическими комплексами с кабельным каналом связи для контроля испытаний и режима 
эксплуатации продуктивных интервалов в режиме реального времени. Также для повышения достоверности полученных данных предлагается вести контроль выработки продуктивных пластов через наблюдательные скважины, оснащенные стеклопластиковыми колоннами, с помощью электрического и индукционного каротажа.

\section{Учебники}

Ибламинов Р.Г. Минерагения (основы минерагеодинамики): учеб. пособие / Р.Г. Ибламинов. Пермь, 2015. 322 с.

Изложено содержание современной минерагении - минерагеодинамики. Рассмотрены геодинамические закономерности размещения полезных ископаемых в современных тектонических обстановках (общая минерагения), в архейскофанерозойской истории Земли (историческая минерагения), тектонические и формационные условия образования месторождений (генетическая минерагения).

Охарактеризованы аспекты прикладной минерагении: методика прогнозирования минерагенических исследований и способы обобщения их результатов.

Методы поисков и разведки месторождений нефти и газа: учебно-метод. пособие / сост. О.Е. Кочнева; Перм. гос. нац. исслед. ун-т. Пермь, 2015. 100 с.

Автором изложены основные методы поисково-разведочных работ на региональном, поисковом и разведочном этапах. Рассмотрено комплексирование методов исследования, позволяющих дать качественную и количественную оценку ресурсам и запасам углеводородного сырья.

\section{Сборники научных трудов}

Геология в развивающемся мире: сб. науч. тр. (по материалам 8-й научнопрактической конференции студентов, аспирантов и молодых ученых с международным участием): в 2 т. / отв. ред. П.А. Белкин. Пермь, 2015. Т. 1. 572 с. Т. 2. $432 \mathrm{c}$.

Материалы 8-й Всероссийской научно-практической конференции, состояв- шейся на геологическом факультете Пермского государственного национального исследовательского университета, отражают тематику курсовых, дипломных и диссертационных работ.

Геология и полезные ископаемые Западного Урала: статьи по материалам Bcepoc. науч.-практ. конф. с междунар. участием / отв. ред. Р.Г. Ибламинов; Перм. гос. нац. исслед. ун-т. Пермь, 2015. $267 \mathrm{c}$.

Материалы региональной научнопрактической конференции, состоявшейся 19-20 мая 2015 г. на геологическом факультете Пермского государственного национального исследовательского университета, посвящены вопросам геологии территорий сочленения платформенныхи складчатых областей на примере Западного Урала и Камского Приуралья. Рассматриваются проблемы прогнозирования месторождений твердых полезных ископаемых (золота, алмазов и т.д.), нефти и газа, вопросы гидрогеологии, инженерной геологии, карстоведения, экологической геологии, физических процессов горного дела, геофизических методов исследования недр.

Проблемы минералогии, петрографии и металлогении. Научные чтения памяти П.Н. Чирвинского: сб. науч. ст. /отв. ред. И.И. Чайковский. Пермь, 2015. Вып. 18. $428 \mathrm{c}$.

Сборник подготовлен по материалам докладов Всероссийской научной конференции с международным участием, состоявшейся 20-21 янв. 2015 г. на кафедре минералогии и петрографии Пермского университета. Содержит результаты исследований, касающихся некоторых проблем минералогии, петрографии, минерагении, геохимии и других наук, которые входили в круг интересов П.Н. Чирвинского.

Россыпи и месторождения кор выветривания: изучение, освоение, экология: материалы 15-го Междунар. совещ. по геологии россыпей и месторождений выветривания (Пермь, 24-28 авг. 2015 г.) / 
Перм. гос. нац. исслед. ун-т. Пермь, 2015. $270 \mathrm{c}$.

В материалах совещания охарактеризованы россыпи, месторождения кор выветривания и техногенно-минеральные образования в системе литогенеза. Рассмотрены оценка и рациональное освоение россыпей, месторождений кор выветривания и техногенных минеральных образований. В ходе совещания обсуждались экологические и инженерногеологические проблемы освоения россыпей, месторождений кор выветривания и техногенных минеральных образований.

Исследована система «коренной источник - россыпь - техногенноминеральные образования». Приведены методы изучения вещественного состава россыпей, месторождений кор выветривания и техногенных минеральных образований.

Теория и практика разведочной и промысловой геофизики: материалы Междунар. науч.-практ. конф. (Пермь, 26-27 нояб. 2015 г.) / гл. ред. В. И. Костицын. Пермь, 2015. 263 с.
Материалы Международной научнопрактической конференции «Теория и практика разведочной и промысловой геофизики», состоявшейся 26-27 ноября 2015 г. в Пермском государственном национальном исследовательском университете, посвящены юбилейным датам предприятий «Пермнефтегеофики» и содержат широкий круг тем, освещающих научные направления современной геофизики.

Экологическая безопасность и строительство в карстовых районах/ под ред. В.Н. Катаева; Перм. гос. нац. исслед. ун-т. Пермь, 2015. 384 с.

Материалы Международного симпозиума, состоявшегося 26-29 мая 2015 г. в Пермском государственном национальном исследовательском университете, содержат статьи, посвященные вопросам изысканий, проектирования, строительства и эксплуатации зданий и сооружений на закарстованных территориях.

\section{Publications of Geological Faculty of the Perm State University in 2015}

\section{I.K. Trubina}

Perm State University, 15 Bukirev Str., Perm 614990, Russia

E-mail: mineral@psu.ru

Bibliography and abstracts of books, textbooks, and Conference Proceedings series of Geological Faculty of Perm State University issued in 2015 are described.

Key words: geology, bibliography, Geological Faculty, Perm State University. 